p-ISSN: $2338-4387$

e-ISSN: $2580-3247$

\title{
ANALISIS RESPON GURU DAN PESERTA DIDIK TERHADAP LKPD IPA BERBASIS INKUIRI TERBIMBING YANG TERINTEGRASI AYAT AL-QURAN DAN HADIST DI SMP ASKHABUL KAHFI
}

\author{
Mia Kumalasari \\ Universitas Negeri Semarang \\ e-mail: mia.160594@gmail.com
}

\begin{abstract}
Abstrak
Penelitian ini bertujuan untuk mengetahui respon guru dan peserta didik terhadap LKPD IPA berbasis inkuiri terbimbing pada pembelajaran ipa yang terintegrasi ayat Al-Quran dan Hadist di SMP Askhabul Kahfi. Penelitian ini dilakukan di SMP Askhabul Kahfi pada bulan November 2018. Penelitian menggunakan lembar observasi, lembar kuesioner, wawancara. Lembar kuesioner diberikan kepada 15 orang peserta didik putra dan 15 orang peserta didik putri. Wawancara dilakukan dengan Kepala Sekolah, Guru IPA dan 2 orang peserta didik yang terdiri atas 1 orang peserta didik putra dan 1 orang peserta didik putri. Hasil diperoleh dianalisis dengan metode deskriptif. Dari penelitian ini dapat disimpulkan bahwa guru dan peserta didik SMP Askhabul Kahfi sangat setuju apabila pembelajaran IPA menggunakan LKPD terintegrasi ayat AI-Quran dan Hadist karena dapat mengaitkan pembelajaran IPA dengan Agama Islam sehingga dapat meningkatkan keimanan peserta didik terhadap Allah SWT.
\end{abstract}

Kata kunci: Inkuiri Terbimbing, LKPD, Al-Quran, Hadist

\section{Abstract}

This study aims to determine the response of teachers and students towards guided inquiry-based LPKD in science learning which integrates verses from the Koran and Hadith at SMP Askhabul Kahfi. This research was conducted at SMP Askhabul Kahfi in November 2018. The study used observation sheets, questionnaire sheets, and interviews. Questionnaire sheets were given to 15 male students and 15 female students. Interviews were conducted on Principals, Science Teachers and 2 students consisting of 1 male student and 1 female student. The results obtained were analyzed with descriptive method. From this study, it can be concluded that SMP Askhabul Kahfi teachers and students strongly agreed when the worksheets (LKPD) is integrated with Koran and Hadith so they can link science and Islam to improve their faith in Allah SWT.

Keywords: Guided Inquiry, Student Worksheets, Kuran, Hadist 


\section{PENDAHULUAN}

Siswadi, at al., (2018) menyatakan bahwa IPA berkaitan dengan cara mencari tahu tentang alam secara sistematis, yang dapat mencari dan menemukan fakta-fakta, konsep-konsep atau prinsip. IPA merupakan ilmu yang mempelajari gejala-gejala alam, peristiwa atau fenomena alam serta berusaha untuk mengungkap segala rahasia dan hukum semesta secara ilmiah yang dapat dikaitkan dengan Al-Quran dan Hadist. Al-Qur'an merupakan sumber informasi sekaligus pedoman dalam setiap aktivitas manusia sehingga dibutuhkan pemahaman yang utuh, yakni dengan memahami ayat-ayat al-Qur'an dan hadist yang dapat dikaitkan dengan IPA. Thanthawi Jauhari, salah satu ahli tafsir yang mahir dalam bidang sains, di dalam kitab tafsirnya "Al-Jawāhir fī Tafsīr Al-Qur"an Al-Karīm", mengatakan bahwa sebenarnya di dalam al-Qur'an terdapat ayat-ayat tentang ilmu pengetahuan yang berjumlah atas 750 ayat, sementara yang membahas tentang ilmu fiqih tandatandanya tidak melebihi dari 150 ayat. Al-Qur'an telah dijelaskan tentang keharusan untuk mengamati fenomena IPA sebagai pengembangan rasa ingin tahu,seperti dalam Surat Yunus ayat 101 Katakanlah:"Perhatikanlah apa yang ada di langit dan dibumi!" Tidaklah bermanfaat tanda-tanda kekuasaan Allah dan rasulrasul yang memberi peringatan bagi orangorang yang tidak beriman".

Latifah dan Ratnasari (2016) menyatakan bahwa peserta didik dalam pembelajaran IPA tidak hanya dituntut untuk mengetahui tentang sains namun juga memahami bahwa keteraturan yang ada dalam alam semesta ini tidak lepas dari kekuasaan Allah SWT sehingga semakin bertambah keyakinan terhadap Tuhan, dan menumbuhan karakter berwawasan keislaman terhadap peserta didik. Upaya menumbuhkan karakter berwawasan keislaman terhadap peserta didik dapat terwujud apabila terdapat perangkat pembelajaran IPA yang terintegrasi ayat AI Quran dan Hadist. Salah satu perangkat pembelajaran yang diperlukan untuk mendukung pembelajaran berwawasan keislaman di sekolah berbasis pondok pesantren yaitu Lembar Kerja Peserta Didik (LKPD) terintegrasi ayat Al Quran dan Hadist.

Surani (2018) menyatakan bahwa LKPD merupakan sumber belajar yang berisi serangkaian kegiatan dan latihan bagi peserta didik untuk mempermudah dan 
meningkatkan pemahaman terhadap materi pembelajaran yang isinya dirancang dan dikembangkan sesuai dengan kondisi dan situasi yang akan dihadapi. Bahan ajar LKPD merupakan salah satu sumber belajar yang dapat dikembangkan oleh pendidik dalam kegiatan pembelajaran. LKPD yang disusun dapat dirancang dan dikembangkan sesuai dengan kondisi dan situasi kegiatan pembelajaran yang akan dihadapi. Diperlukan suatu pendekatan agar LKPD dapat mempermudah peserta didik dalam mengerjakan tugas secara mandiri maupun berkelompok.

Pendekatan yang digunakan untuk menanamkan keterampilan berfikir kritis, aktif dan ilmiah serta melatih peserta didik SMP melakukan suatu penemuan yaitu inkuiri terbimbing. Hamdayama (2014: 31) menyatakan bahwa inkuiri berasal dari kata to inquire (inquiry) yang berarti ikut serta atau terlibat, dalam mengajukan pertanyaan-pertanyaan, mencari informasi, dan melakukan penyelidikan. Model pembelajaran inkuiri terbimbing peserta didik menjadi pusat pembelajaran sedangkan guru hanya sebagai pembimbing yang memberikan instruksi kepada peserta didik untuk melakukan suatu identifikasi yang sesuai dengan yang terjadi di alam sekitar (Azizmalayeri et al., 2012).

Hasil pengamatan dari Arumayanti (2017) LKPD yang digunakan guru di MI Masyariqul Anwar Bandar Lampung sebelumnya belum ada lembar kerja untuk peserta didik melakukan inkuiri (penemuan). Selaras dengan hasil wawancara oleh Muchlisoh (2014) di SMP Negeri 5 Yogyakarta yang juga memperoleh informasi bahwa pembelajaran Kurikulum 2013 sudah lancar namun guru masih kesulitan dalam mengembangkan LKPD yang sesuai Kurikulum 2013. Selain itu LKPD yang berdasarkan Kurikulum 2013 masih jarang dipasarkan. Buku peserta didik yang diberikan hanya memuat sedikit materi yang singkat sehingga peserta didik sangat membutuhkan adanya LKPD, terutama LKPD berbasis inkuiri terbimbing yang terintegrasi ayat Al-Quran dan Hadist. Maka diperlukan adanya studi pendahuluan mengenai respon guru dan peserta didik terhadap LKPD berbasis inkuiri terbimbing yang terintegrasi ayat al-quran dan hadist di sekolah berbasis pondok pesantren terutama pada tema tumbuhan. 


\section{METODE}

Metode yang digunakan dalam penelitian ini adalah metode kualitatif dengan menggunakan kuesioner, wawancara, observasi dan dokumentasi. Penelitian kualitatif disebut interpretative inquiry karena banyak melibatkan faktor subjektif, baik dari informan, subjek penelitian maupun peneliti itu sendiri (Irawan, 2006). Populasi adalah wilayah generalisasi yang terdiri atas obyek/subyek yang mempunyai kualitas dan karakteristik tertentu yang ditetapkan oleh peneliti untuk dipelajari dan kemudian ditarik kesimpulannya (Sugiyono, 2013). Populasi dalam penelitian ini adalah seluruh peserta didik kelas VIII SMP Askhabul Kahfi yang terbagi atas 6 kelas. Dalam penelitian ini, cara pengambilan sampel menggunakan teknik cluster random sampling. Cluster random sampling yaitu teknik penarikan sampel yang digunakan apabila populasi atau sampel yang tersedia adalah berupa unit-unit rumpun dalam populasi (Setyosari, 2012).

Tabel 1. Sebaran Populasi dan Responden Berdasarkan Jabatan

\begin{tabular}{llcc}
\hline \multirow{2}{*}{ No. } & \multicolumn{1}{c}{ Jenis Kelamin } & \multicolumn{2}{c}{ Jumlah Responden } \\
\cline { 3 - 4 } & Peserta didik & Putra & Putri \\
\hline 1 & Guru IPA & 15 & 15 \\
3 & Kepala SMP & 1 & 1 \\
\hline Total & & 16 & 16 \\
\hline
\end{tabular}

\section{HASIL DAN PEMBAHASAN}

Penelitian ini dilakukan di SMP Askhabul Kahfi pada bulan Oktober 2018. Berdasarkan hasil observasi diperoleh hasil bahwa SMP Askhabul Kahfi yang merupakan sekolah yang berbasis Pondok Pesantren belum memiliki laboratorium IPA. Buku paket yang digunakan peserta didik sudah ada, namun tidak bisa di bawa pulang ke pondok. Penelitian ini menggunakan responden sebanyak 30 peserta didik yang terdiri dari 15 peserta didik putra dan 15 peserta didik putri.

Hasil kuesioner menunjukkan hasil 100\% menyatakan bahwa pembelajaran IPA di sekolah sering menggunakan kerja kelompok. Hasil wawancara dengan peserta didik Responden 1 dan Responden 2 memperoleh hasil bahwa pembelajaran IPA di SMP Askhabul Kahfi hampir setiap penyampaian materi guru selalu membentuk peserta didik menjadi kelompok-kelompok kecil. Hal ini sesuai 
dengan tuntutan Kurikulum 2013 yang menghendaki pembelajaran menggunakan kerja kelompok. Namun, pembelajaran IPA tidak selalu dikaitkan dengan Ayat AlQuran dan Hadist. Menurut hasil wawancara dengan Responden 4 yang merupakan guru IPA SMP Askhabul Kahfi sangat setuju apabila pembelajaran dapat dikaitkan dengan Al-Quran dan Hadist. Responden 3 yang merupakan kepala sekolah SMP Askhabul Kahfi juga mengatakan jika beliau sangat setuju apabila pembelajaran selalu dikaitkan dengan Al-Quran dan Hadist karena dapat meningkatkan keimanan peserta didik kepada Allah SWT, terlebih lagi SMP Askhabul Kahfi merupakan sekolahan yang berbasis pondok pesantren sehingga sangat penting apabila pembelajaran dikaitkan dengan Al-Quran dan Hadist.

Peserta didik cenderung mengharapkan adanya LKPD pada pembelajaran IPA. Menurut Citradevi, Widyatmoko, \& Khusniati (2017) lembar kerja disusun dengan pembelajaran berbasis proyek karena menggunakan metode pembelajaran, peserta didik dapat terlibat langsung dalam proses pembelajaran karena ada proyek yang diselesaikan secara individu atau dalam kelompok. Menurut hasil wawancara dengan guru IPA dan wawancara dengan peserta didik menyatakan bahwa Pembelajaran IPA di sekolah belum menggunakan LKPD yang dikaitkan dengan AlQuran dan Hadist. Namun, 60\% peserta didik putra dan $86.7 \%$ peserta didik putri menginginkan jika pembejaran IPA dapat menggunakan LKPD yang dikaitkan dengan Ayat Al-Quran dan Hadist karena mereka lebih bersemangat jika pembejaran IPA menggunakan LKPD dikaitkan dengan Ayat AI-Quran dan Hadist. Menurut peserta didik, pembejaran IPA yang menggunakan LKPD yang dikaitkan dengan Ayat Al-Quran dan Hadist dapat meningkatkan rasa keingintahuan Anda terhadap pembelajaran IPA. Peserta didik menginginkan LKPD dalam pembejaran IPA yang dikaitkan dengan Ayat Al-Quran dan Hadist dilengkapi gambar yang berwarna dan design yang menarik. Menurut peserta didik pembelajaran IPA akan menjadi lebih bersemangat jika LKPD dalam pembejaran IPA yang dikaitkan dengan Ayat Al-Quran dan Hadist dilengkapi dengan gambar yang berwarna design yang menarik. $67 \%$ peserta didik putra dan $86.7 \%$ peserta didik putri ingin pembejaran IPA yang menggunakan LKPD yang dikaitkan dengan Ayat Al-Quran dan Hadist dapat lebih menghemat waktu dan tenaga (efisien). 
Menurut 33\% peserta didik putra dan $86.7 \%$ peserta didik putri pembejaran IPA yang menggunakan LKPD yang dikaitkan dengan Ayat AI-Quran dan Hadist dapat membuat kerja kelompok dapat diselesaikan dengan tepat waktu (efektif) dan ingin jika LKPD dilengkapi langsung dengan ayat Al Quran dan Hadist yang berkaitan dengan konsep IPA. Diharapkan dengan adanya LKPD dapat menyajikan konten yang otentik bagi peserta didik untuk membuat suatu kesimpulan pembelajaran IPA yang berkaitan Ayat AI-Quran dan Hadist. Hal ini sesuai dengan pernyataan Adams \& Luft (2018) bahwa konten perlu disajikan dengan cara otentik yang memungkinkan peserta didik untuk memahami bagaimana para ilmuwan melakukan eksperimen, jenis pertanyaan yang diajukan, dan bagaimana kesimpulan dibuat.

Hasil wawancara dengan Kepala SMP Askhabul Kahfi mengatakan bahwa sangat setuju apabila ada LKPD yang terintegrasi ayat Al-Quran dan Hadist karena dapat meningkatkan keimanan dan ketaqwaan kepada Allah SWT, selain itu peserta didik juga dapat mengetahui hubungan antara agama dan ilmu pengetahuan alam yang diharapkan dapat membuat perilaku peserta didik sesuai dengan norma agama dan sosial yang berlaku di masyarakat. LKPD yang terintegrasi ayat Al-Quran dan Hadist ini dapat mengatasi permasalahan peserta didik yang belum bisa memahami aplikasi sains dalam kehidupan dan agama. Menurut pernyataan dari Dimas bahwa dia sulit mengaitkan antara pembelajaran IPA dengan kehidupan dan agama. Hal ini sesuai dengan hasil Wahyuningsih, Rusilowati \& Hindarto (2017) menyatakan bahwa peserta didik tidak memahami hubungan aplikasi sains dengan teknologi, masyarakat, dan lingkungan berdasarkan moral dan perilaku yang sesuai.

Maka dari itu perlu adanya pembaharuan disain pembelajaran yang mengaitkan antara IPA dan ilmu agama, yaitu LKPD terintergasi ayat AI-Quran dan Hadis. Hal ini karena pendidikan membutuhkan untuk merenungkan proses pendidikan yang digabungkan dan mengembangkannya dalam kerangka pendekatan, metodologi, pengetahuan, dan hubungan baru antara agen pendidikan yang berbeda (María, et al. 2018). Berawal dari kriteria ayat-ayat yang mengandung pembelajaran IPA, maka dilakukan upaya pencarian dan pengumpulan ayat yang berkaitan dengan pembelajaran IPA. Proses pembelajaran al-Qur"an 
memperlihatkan semua komponen memiliki satu kesatuan yang utuh dan lengkap. Dimulai dari unsur pembelajar (guru), pebelajar (peserta didik), materi, media, metode, dan diakhiri dengan evaluasi.

\section{SIMPULAN}

Simpulan dari penelitian ini adalah bahwa guru dan peserta didik SMP Askhabul Kahfi merespon dengan baik dan sangat setuju apabila pembelajaran IPA menggunakan LKPD terintegrasi ayat AI-Quran dan Hadist karena dapat mengaitkan pembelajaran IPA dengan Agama Islam sehingga dapat meningkatkan keimanan peserta didik terhadap Allah SWT.

\section{DAFTAR PUSTAKA}

Adams, Krista L, and Julie A Luft. 2018. "Beginning Chemistry Teachers ' Depictions of the Chemistry Content." 13(1): 69-95.

Citradevi, Widyatmoko, \& Khusniati. 2017. "The Effectiveness Of Project Based Learning ( Pjbl ) Worksheet To Improve Science Process Skill For Seven Graders Of Junior High School In The Topic Of Environmental Pollution." 6(3): 1677-85.

Irawan, P. 2006. Penelitian Kualitatif dan Kuantitatif untuk IImu-ilmu Sosial. Jakarta: Departemen IImu Adaministrasi, Fakultas IImu Sosial dan Politik, UI.

Latifah, S., \& Ratnasari. 2016. Pengembangan Modul IPA Terpadu Terintegrasi Ayat-Ayat Al-Qur'an pada Materi Tata Surya. Jurnal Penelitian Pembelajaran Fisika. 7(1) 25-33

María, José, Fernández Batanero, Miguel María Reyes, and Rocío Piñero. 2018. "Design, Application and Evaluation of a Technological Instrument about Environmental Education." 13(7): 579-88.

Siswadi. 2014. Pengaruh Pendekatan VAK (Visualization, Auditory, Kinestetic) terhadap Hasil Belajar Fisika Peserta didik SMPN 10 Mataram tahun Ajaran 2013/2014. Skripsi. Tidak Dipublikasikan. Universitas Mataram: Mataram.

Siswadi., Susilawati., \& Hikmawati. 2018. Pengaruh Pendekatan Vak (Visualization, Auditory, Kinestetic) Terhadap Hasil Belajar Fisika Siswa SMPN 10 Mataram. Jurnal Penelitian Pendidikan IPA. 4(1).

Sugiyono. 2013. Statistika untuk Penelitian. Bandung: Alfabeta. 
Wahyuningsih, S., Rusilowati, A., \& Hindarto, N. (2017). Analysis ff Misconception to Science Literacy Using Three Tier Multiple Choice Test In The Materials of Characteristic Of Light. Unnes Science Education Journal, 6(3). 